\title{
STUDENTS PERSPECTIVES ON THE USE OF INNOVATIVE AND INTERACTIVE TEACHING METHODS AT THE UNIVERSITY OF NOUAKCHOTT AL AASRIYA, MAURITANIA: ENGLISH DEPARTMENT AS A CASE STUDY
}

Taleb Bilal Eli

English Department, University of Nouakchott Al Aasriya, Mauritania, talebiano@yahoo.com

\begin{abstract}
This study was carried to inspect students 'views on the use of innovative and interactive teaching methods used in the English studies major at the University of Nouakchott Al Aasriya, Mauritania. This was a corollary of the fact that innovation in teaching, regardless the nature of the course or subject, has become a buzz word in the academic institutions. A quantitative research methodology was used and the data were collected from 101 students from the English Department. The collected data were analyzed using SPSS as an attempt to provide descriptive statistics to verify the students` perception of the use of innovative and interactive teaching methods. The findings of the study revealed that $91.1 \%$ of the students believe that their teachers do use some of the innovative and interactive teaching methods in their classes; still, $70.3 \%$ of the respondents were in favor of continuous trainings for teachers on the use of innovative and interactive teaching methods, which is a very alarming percentage. Also, the findings of this study have some significant implications such as the necessity to move from teaching to learning as an attempt to make learning an enjoyable and memorable experience. The results of this study contribute to literature by concentrating on the use of innovative and interactive teaching methods in Mauritanian higher education institutes.
\end{abstract}

Keywords: Innovative, Interactive, Teaching Methods, Students, Higher Education, Mauritania 


\section{INTRODUCTION}

Teaching and learning are two facets of a coin with untarnished affinity. This lustrous affinity makes it clear that the two terms are a mirror image of each other. Nowadays, the term innovation has recently become a synonym for the term learning. Therefore, it becomes vital for teaching effectiveness committees and educators across the globe to think about the most effective, innovative and interactive teaching methodologies that can boost students`learning and impact their performance.

Innovative and interactive teaching methods can be defined as strategies of learning used to improve students learning and skills through different ways of engagements inside and outside the classroom. To put it crudely, innovative and interactive teaching methods are techniques/activities used to create a sort of interaction between students and the teacher and more importantly make the learning an enjoyable and memorable experience. This emanates from the fact that the new generation is no longer adaptive to the traditional teaching and learning methods due to many reasons. One of these reasons might be the disruption created by the digital age which may have changed class dynamics.

In $21^{\text {st }}$ century, innovative and interactive teaching methods have been seen as very essential tools to move from teaching to learning. However, the fact that Mauritania is one of the developing countries with limited teaching facilities and resources makes it a bit difficult to implement most of the interactive and innovative teaching methods. This urges higher education committees to work on very clear strategic plans in which the efforts should be made in unraveling ways to expose university students to the current innovative and interactive teaching methods to improve their performances, rather than sticking to the old teaching methods which might somehow be obsolete. As a result, this latter calls for studies that test students perception of the use of innovative and interactive teaching methods as an attempt to take teaching and learning to the next level. Significantly, the study is guided by following research questions:

1. Is it important to use innovative and interactive teaching methods in order to improve students` learning? 
2. What types of innovative and interactive teaching methods do the faculty members use?

3. How many teachers use innovative and interactive teaching methods in their classes?

4. Do teachers struggle to make learning a memorable experience?

5. Do you think that teachers at the English department need to be trained on how to make learning a memorable experience through innovative and interactive teaching methods?

\section{Literature Review}

Numerous studies have dealt with the aforementioned topic due to its importance in to teaching and learning when it comes to enhancing students' performance. Now, universities started emphasizing the significance of recruiting lecturers with innovative traits such as humility, courage, impartiality, open-mindedness, empathy, enthusiasm, judgement and imagination (Hare, 1993; cited in Wickramasinghe \& Upeksha, 2016). It has been proved in many studies that distinguished teaching awards in most cases go to those innovative teachers (Lunde \& Wilhite, 1996).

Of course, teachers differ in their teaching strategies. Therefore, they use different teaching methods depending on what type of courses, what type of students, number of the students and the equipment available in the classroom (Wickramasinghe \& Upeksha, 2016). Though, there are many teaching strategies and methods; however, not all of them can guarantee an interactive and innovative teaching atmosphere. This includes student-centered-learning, learning by doing, gamification, think-pair-share, group discussion, learning stations, flipped classroom and role play. Additionally, the implementation and execution of these innovative and interactive teaching methods in classrooms will surely improve the quality of education and more importantly make learning an enjoyable experience for the students (Wickramasinghe \& Upeksha, 2016).

Furthermore, it has been argued that education is a considerable instrument for social change and transformation; and innovative and interactive teaching methods are the only ways to boost the quality of education (Nicolaides, 2012). As a result, it becomes almost mandatory for the academics to be innovative in the way they deliver their courses and impart new skills and prepare the students for the challenges of the $21^{\text {st }}$ century (Bawuro, 2018). Specifically, education is in a 
critical situation that requires varieties of alternatives and solutions to surmount the challenges (Abu Yazid, 2016); and that will not be possible unless we take innovative teaching methods into consideration.

As Zhang Shuguo (2012) argued that education should be characterized by innovative ideas and teaching practices of innovation which are meant to change and reform the old teaching ways and models and establish a new innovation-oriented education in order to realize the objectives. Generally, the teaching strategy includes some practices and activities implemented by the faculty members to enhance students` learning. However, the teaching methods that the teacher is going to use should take into consideration the subject and nature of the course as well as the leaners. (Hashim et al., 2019)

Additionally, there are many factors that can impact the teaching methods that the faculty members used in their teaching. For example, class strength, the nature of teachers`contract, school location and the academic background and gender of the faculty member (Shinn, 1007). Still, some faculty members are very traditional in their teaching, following the conventional methods of teaching and learning. For instance, students come and take the course materials and memorize the necessary information which is an old-fashioned teaching methods (Azman et al., 2018).

Innovation and students`engagement are very much required in modern teaching not only as a way of following the pace of globalization, but rather to improve teaching and learning. For example, student-centred-learning method, gamification, group discussion, learning stations, role play, learning by doing have been proved to be very effective in teaching and learning. There is a growing evidence that student-centered approach is very effective and has a great impact on students' performance. Handelsman et al (2004), in their article entitled: Scientific Teaching, argued that "there is mounting evidence that supplementing or replacing lectures with active learning strategies and engaging students in discovery and scientific process improves learning and knowledge retention". (pp., 521-522)

In their research on student-centered-learning, researchers have tried to discuss and question the balance of power between student and the teacher as an attempt to decipher the best practices that 
can improve students` learning (Bacon, 1983; Bell, 1993; Estes \& Tomb, 1995; Priest \& Gass, 1997; Vokey, 1987). Some have also argued that when instructors impose their opinions on their students, rather than providing an enjoyable experience, they are putting their students on the periphery in terms of learning. Brown (2002a, 2002b) argued that teacher usually imposed the teacher-centered behavior when he or she (a) assesses his or her students whether their answers are right or wrong, (b) when he/she frames the students`comments to be acceptable by stating what the students meant, (c) when he/ she gives the students the chance to talk, (d) when he/she instructs the students to talk to him/her rather giving the students the chance to talk to each other. Weimer (2002) in her Learner-centered teaching: Five key changes to practice, recommended that the faculty members should start sharing the power with the students, giving them the chance to choose some of the class activities and assignments that they prefer to do. This is one way to empower students and involve them in the learning process.

Another innovative and interactive teaching method which is used by most of the innovative teachers is gamification. Hamari et al. (2014) stated that "during the last couple of years, gamification has been a trending topic and a subject to much hype as a means of supporting user engagement and enhancing positive patterns in service use, such as increasing user activity, social interaction, or quality and productivity of actions. (p. 1) Furthermore, another teaching strategy that has been discussed and studied by many researchers is the Think-Pair-Share strategy. Researchers argued that think-pair-share is very effective when it comes to students`speaking skills. According to Lyman (1987), think-pair-share is a strategy designed to improve students' collaborative skills and share their ideas and thoughts with other students.

To analyze the significance of teaching strategies in students` retention, Uqwuanyi et al. (2020) argued that flipped classroom strategies is very effective when it comes to enhancing the achievement and retention of physics students: "it was recommended among others that state government in synergy with the school authorities should provide good flipped classroom facilities which will aid students' achievement and technological development to compete with the world at large" (Uqwuanyi et al., 2020). Additionally, there are many other learning strategies proposed by Milada Broukals such as scanning, skimming for details and making inferences and drawing conlusion that enhance students' autonomy and communication skills when it comes to English 
learners (Eli, 2016). Thus, it becomes clear through the literature review that innovative and interactive teaching methods that this paper addresses are very important since the world is going through a considerable transformation at all the domains and education is one of them.

\section{METHODOLOGY}

In this research paper, a quantitative research design was used where data were collected as per the availability and convenience of the respondents. Closed-ended questions were distributed to the students via google form document which was the main instrument for the data collection along with 3 class representatives who were encouraging students to participate in the survey. Finally, 101 responses were collected. In the questionnaire, students were asked to read and give answers that best describe their opinions on the use of innovative and interactive teaching methods in courses taught at the English department. Students talked about innovation and their

understanding of the overall idea of innovation in teaching, including what faculty members should do in order to improve teaching and learning. Then, data were examined using SPSS (Statistical Package for the Social Sciences).

\section{DATA ANALYSIS}

This part of the paper will try to expose the findings of the data obtained from the closed-ended questionnaire. The findings of this study are divided into two sections. Section one is mainly about the demographic of the participants and the second section is on the use of innovative and interactive teaching methods in Mauritanian higher institutes.

\section{The demographic of the study sample}

\subsection{Students Gender}

Respondents were asked to identify their gender. Table 1 shows that a total of $58(57.4 \%)$ of the respondents were males, while 43 of them (42.6\%) are female students. 
Table 1: Respondents Gender

\begin{tabular}{cllll}
\hline Student Gender & Frequency & Percent & Valid Percent $\begin{array}{l}\text { Cumulative } \\
\text { Percent }\end{array}$ \\
\hline Male & 58 & 57.4 & 57.4 & 57.4 \\
Female & 43 & 42.6 & 42.6 & 100.0 \\
Total & 101 & 100.0 & 100.0 & \\
\hline
\end{tabular}

1.2 Students Age

Respondents were asked to indicate their category. Table 2 reveals that most of the respondents 83 $(82.2 \%)$ belong the category (18-24) years old, and 18 respondents $(17.8 \%)$ belong to the category (25-30) years old.

Table 2: Students Age

\begin{tabular}{cllll}
\hline Students Age & Frequency & Percent & Valid Percent $\begin{array}{c}\text { Cumulative } \\
\text { Percent }\end{array}$ \\
\hline 18-24 years & 83 & 82.2 & 82.2 & 82.2 \\
25-30 years & 18 & 17.8 & 17.8 & 100.0 \\
Total & 101 & 100.0 & 100.0 & \\
\hline
\end{tabular}

1.3 Level of the Study

Participants were asked to tick their level of study. Table 3 tells about the fact that $39(38.6 \%)$ of the respondents are from the $1^{\text {st }}$ year; $33(32.7 \%)$ are from $2^{\text {nd }}$ year; and $29(28.9 \%)$ are from the $3^{\text {rd }}$ year.

Table 3: Level of study

\begin{tabular}{lllll}
\hline Level of Study & Frequency & Percent & Valid Percent & $\begin{array}{l}\text { Cumulative } \\
\text { Percent }\end{array}$ \\
\hline 1st Year (L1) & 39 & 38.6 & 38.6 & 38.6 \\
2nd Year (L2) & 33 & 32.7 & 32.7 & 71.3 \\
3rd Year (L3) & 29 & 28.7 & 28.7 & 100.0 \\
Total & 101 & 100.0 & 100.0 & \\
\hline
\end{tabular}


2. Research Questions: Students`Perspectives on the Use of Innovative and Interactive Teaching Methods

2.1 Research question One: Is it important to use innovative and interactive teaching methods in order to improve students` learning?

Students were asked to identify the best options that describe their views on the importance of innovative teaching methods in the classroom. Table 4 shows that $41(40 \%)$ answered with strongly agree; $55(50.5 \%)$ with agree; 5 (5.0\%) were neutral; 2 (2.0\%) with disagree; $2(2.0 \%)$ with strongly disagree.

Table 4: Students` responses on the importance of the innovative and interactive methods.

\begin{tabular}{lllll}
\hline $\begin{array}{l}\text { Importance of IITM in } \\
\text { classroom }\end{array}$ & Frequency & Percent & Valid Percent $\begin{array}{l}\text { Cumulative } \\
\text { Percent }\end{array}$ \\
\hline Strongly Disagree & 2 & 2.0 & 2.0 & 2.0 \\
Disagree & 2 & 2.0 & 2.0 & 4.0 \\
Neutral & 5 & 5.0 & 5.0 & 8.9 \\
Agree & 51 & 50.5 & 50.5 & 59.4 \\
Strongly Agree & 41 & 40.6 & 40.6 & 100.0 \\
Total & 101 & 100.0 & 100.0 & \\
\hline
\end{tabular}

2.2 Research question two: What types of innovative and interactive teaching methods do the faculty members use?

Respondents were asked to indicate the types of innovative and interactive teaching methods used by the faculty members. Table 5 reveals that 38 (37.6\%) answered with group discussion; 32 (31.7\%) with learning by doing; 12 (11.9\%) with student-centered-learning; 4 (4.0\%) with thinpair-share; 3 (3.0\%) with gamification; 2 (2.0\%) with learning stations, flipped classroom and just usual learning; 6 (5.9\%) answered with none. 
Table 5: Types of innovative and interactive teaching methods used by the faculty members.

\begin{tabular}{lllll}
\hline $\begin{array}{l}\text { Types of IITM used by } \\
\text { teachers }\end{array}$ & the Frequency & Percent & Valid Percent $\begin{array}{c}\text { Cumulative } \\
\text { Percent }\end{array}$ \\
\hline Student-Centered-Learning & 12 & 11.9 & 11.9 & 11.9 \\
Learning by Doing & 32 & 31.7 & 31.7 & 43.6 \\
Gamification & 3 & 3.0 & 3.0 & 46.5 \\
Think Pair Share & 4 & 4.0 & 4.0 & 50.5 \\
Group Discussion & 38 & 37.6 & 37.6 & 88.1 \\
Learning Stations & 2 & 2.0 & 2.0 & 90.1 \\
Flipped Classroom & 2 & 2.0 & 2.0 & 92.1 \\
Just Usual Learning & 2 & 2.0 & 2.0 & 94.1 \\
None & 6 & 5.9 & 5.9 & 100.0 \\
Total & 101 & 100.0 & 100.0 & \\
\hline
\end{tabular}

2.3 Research question three: How do you see the success of the use of interactive and innovative teaching methods used by your teachers?

Respondents were asked about the success of innovative and interactive methods used by the teachers. Table 6 indicates that 9 (8.9\%) answered with excellent; 20 (19.8) with very good; 43 (42.6\%) answered with good; and 11 (10.9\%) with poor.

Table 6: Students' views on the success of innovative teaching methods.

\begin{tabular}{|c|c|c|c|c|c|}
\hline $\begin{array}{l}\text { Student } \\
\text { the s } \\
\text { IITM }\end{array}$ & $\begin{array}{l}\text { ts' views on } \\
\text { success of }\end{array}$ & Frequency & Percent & Valid Percent & $\begin{array}{l}\text { Cumulative } \\
\text { Percent }\end{array}$ \\
\hline & Excellent & 9 & 8.9 & 8.9 & 8.9 \\
\hline & Very Good & 20 & 19.8 & 19.8 & 28.7 \\
\hline & Good & 43 & 42.6 & 42.6 & 71.3 \\
\hline & Fair & 11 & 10.9 & 10.9 & 82.2 \\
\hline & Poor & 18 & 17.8 & 17.8 & 100.0 \\
\hline & Total & 101 & 100.0 & 100.0 & \\
\hline
\end{tabular}


2.4 Research question four: Do teachers struggle to make learning a memorable experience?

Participants were asked to choose the best options that describe their opinions. Table 7 shows that $50(49.5 \%)$ answered with Yes; $40(39.6 \%)$ with No and $11(10.9 \%)$ with 'some of them.

Table 7: respondents` views on whether teachers struggle to make learning a memorable experience.

\begin{tabular}{|c|c|c|c|c|}
\hline $\begin{array}{l}\text { Students' views on } \\
\text { teachers' effort to use } \\
\text { IITM }\end{array}$ & Frequency & Percent & Valid Percent & $\begin{array}{l}\text { Cumulative } \\
\text { Percent }\end{array}$ \\
\hline Yes & 50 & 49.5 & 49.5 & 49.5 \\
\hline No & 40 & 39.6 & 39.6 & 89.1 \\
\hline Some of them & 11 & 10.9 & 10.9 & 100.0 \\
\hline Total & 101 & 100.0 & 100.0 & \\
\hline
\end{tabular}

2.5 Research question Five: Do you think that teachers at English department need to be trained on how to make learning a memorable experience through innovative and interactive methods?

Students were asked to identify the best options that describe their views on whether training for teachers on how to use innovative and interactive teaching methods is needed. Table 8 indicates that $71(70.3 \%)$ answered with Yes; 6 (5.9\%) with No; and $24(23.8 \%)$ with maybe.

Table 8: Students`views on whether teachers should be trained on the use of innovative and interactive teaching methods or not.

\begin{tabular}{|c|c|c|c|c|}
\hline $\begin{array}{l}\text { Students views } \\
\text { trainings needed }\end{array}$ & Frequency & Percent & Valid Percent & $\begin{array}{l}\text { Cumulative } \\
\text { Percent }\end{array}$ \\
\hline Yes & 71 & 70.3 & 70.3 & 70.3 \\
\hline No & 6 & 5.9 & 5.9 & 76.2 \\
\hline Maybe & 24 & 23.8 & 23.8 & 100.0 \\
\hline Total & 101 & 100.0 & 100.0 & \\
\hline
\end{tabular}




\section{DISCUSSION OF THE FINDINGS}

Result in table 4 on students `responses regarding the importance of the innovative and interactive methods revealed positive responses in favor of the use of these innovative and interactive methods. The total number of the strongly agree/agree exceeds $91.1 \%$ of the total number of the respondents. Also, the use of the innovative and interactive teaching methods by the teachers is very promising, but the types of these methods used need a thorough analysis. For example, group discussion which is not the most innovative teaching method in comparison with student-centeredlearning, flipped classroom and gamification, got the highest percentage as it can be seen in table 5. Furthermore, table 6 indicates that students have positive impressions on the innovative and interactive teaching methods used by the teachers.

Additionally, result in table 7 is very problematic since the total number of those who believe that the teachers strive to make learning an enjoyable experience is very close to who answered with No. This suggests that more efforts need to done by the faculty members to minimize this gap. Moreover, the fact that $10.9 \%$ of the respondents think that only some teachers struggle to make learning a memorable experience remains an issue of concern. Result in table 8 is very alarming since $70.3 \%$ of the students believe that teachers need to be trained on the use of innovative and interactive teaching methods in the classrooms.

\section{CONCLUSION AND IMPLICATIONS}

Innovative and interactive teaching methods are very essential in satisfying the needs of the new generation of students whose fascination with innovation, technology and new ways of life is immense. Based the survey conducted, it is clear that interactive and innovative teaching methods are vital in creating a better environment for students and make their learning an enjoyable experience. To conclude, the findings of this study suggest the following implications:

1. Emphasis should be on the current innovative and interactive teaching methods not on the traditional ones such as group discussion as stated by the students. It's high time to move from teaching to learning; 
2. The faculty members should select the most recent and suitable methods for their students;

3. Faculty members should involve the students in the selection of the class activities as a way of implementing the student-centered-learning;

4. The university/institutions should help the faculty members and give them the necessary tools to come up with creative ideas and implement them in the classrooms;

5. Professional skills development programs need to be initiated to enable knowledge sharing among the faculty members. Each can come with some propositions to improve teaching.

All in all, in a country like Mauritania a lot of efforts need to be done in terms of the implementation of innovative and interactive teaching methods. Additionally, the faculty members on the other hand, need to be aware of the needs and aspirations of the new generation. Also, the institution needs to provide the necessary materials to enable the faculty members to be creative and do the job in an innovative manner.

\section{REFERENCES}

1. Abu Yazid, A. B. (2016). "Digital Classroom": An Innovative Teaching and Learning Technique for Gifted Learners Using ICT. Creative Education, 7, 55-61. https://doi.org/10.4236/ce.2016.71006.

2. Azman, M. N. B., Shuraimi, F. B. M., \& Yunus, M. M. (2018). Enhancing English Language Learning and Teaching via Qgram (Telegram and Quizlet) Innovation. International Journal of Academic Research in Progressive Education and Development, 7, 435-446.

3. Bacon, S. (1983). The conscious use of metaphor in Outward Bound. Denver, CO: Colorado Outward Bound School.

4. Bawuro, F. A. (2018). Factors Influencing Innovative Behavior of Teachers in Secondary Schools in the North East of Nigeria. Path of Science, 4, 1007-1017. https://doi.org/10.22178/pos.32-9. 
5. Bell, M. (1993). What constitutes experience? Rethinking theoretical assumptions. Journal of Experiential Education, 16(1), 19-24.

6. Brown, M. (2002a). Interaction and social order in adventure education facilitation sessions. Unpublished doctoral dissertation, School of Education, The University of Queensland, St. Lucia, Brisbane, Australia.

7. Brown, M. (2002b). The facilitator as gatekeeper: A critical analysis of social order in facilitation sessions. Journal of Adventure Education and Outdoor Learning, 2(2), 101112.

8. Eli, T. B. (2016). Promoting Students Autonomy Though THROUGH Milada Broukals Strategies of Learning: The Case of English 101 and English 102. International Educational Scientific Research Journal. Volume 2, (8). https://issuu.com/internationaleducationalscientificr/docs/16-taleb_bilal.

9. Estes, C. A., \& Tomb, S. (1995). Is cheese food really food? a.k.a. Some conscious alternatives to overpro-cessing experience. Paper presented at the 1995 International Conference on Outdoor Recreation and Education. (ERIC Document Reproduction Service No. ED404080).

10. Hamari, J., Koivisto, J., \& Sarsa, H. (2014). Does Gamification Work? - A Literature Review of Empirical Studies on Gamification. In proceedings of the 47th Hawaii International Conference on System Sciences, Hawaii, USA, January 6-9, 2014.

11. Handelsman, J., Ebert-May, D., Beichner, R., Bruns, P., Chang, A., DeHaan, R., et al. (2004). Scientific teaching. Science 304(5670), 521-522.

12. Hare, W. (1993). Open-Mindedness and Education. McGill-Queen's Press-MQUP.

13. Hashim, H., Saharani, M., Zulkifli, N., Mokhtar, M. and Yunus, M. (2019) Conception of Innovative Teaching Methodologies among Lecturers at Selected Polytechnics in Malaysia. Creative Education, 10, 874-881. doi: 10.4236/ce.2019.105065.

14. Lunde, J. P., \& Wilhite, M. S. (1996). Innovative Teaching and Teaching Improvement. Professional and Organizational Development. Network in Higher Education. https://digitalcommons.unl.edu/.

15. Lyman, F. (1987). Think-Pair-Share: An Expanding Teaching Technique: MAA-CIE Cooperative News. Nagata, K. \& Ronkowsk, S. (1998). Collaborative Learning: Differences Between Collaborative and Cooperative Learning, The Office of Instructional Consultation, University of California Santa Barbara.

16. Nicolaides, A. (2012). Innovative Teaching and Learning Methodologies for Higher Education Institutions. Educational Research, 3, 620-626.

17. Priest, S., \& Gass, M. A. (1997). Effective leadership in adventure programming. Champaign, IL: Human Kinetics.

18. Ugwuanyia, C. S., Ndujib, C.C., Elejerc, U.C., \& Omeked, N.E. (2020). Effect of Flipped Classroom and Think Pair Share Strategy on Achievement and Retention Among Senior Secondary School Physics Students. International Journal of Sciences: Basic and Applied 19. Research (IJSBAR) (2020) Volume 52, No 2, pp 136-148.

20. Vokey, D. (1987). Outward Bound: In search of foundations. Unpublished doctoral dissertation, Queen's University, Kingston, Ontario, Canada.

21. Weimer, M. (2002). Learner-centered teaching: Five key changes to practice. San Francisco, CA: Jossey-Bass. 
22. Wickramasinghe, S., \& Upeksha, G. N. (2016). Innovative and Interactive Teaching Methods for Improving Learning Quality in Higher Education. 2nd International Conference on Education and Distance Learning, Colombo, Sri Lanka, 1 July 2016, 1-11.

23. Zhang, S. G. (2012). Higher Education Research and Practice of College Students' Innovative Exploration. Hudson Normal University (Humanities and Social Sciences), 1, 168-170.

24. Ali, N., Ghazal, T., Ahmed, A., Abbas, S., Khan, M., Alzoubi, H., Farooq, U., Ahmed, M. \& Khan, M. (2021) Fusion-Based Supply Chain Collaboration Using Machine Learning Techniques. Intelligent Automation \& Soft Computing, 31(3), 1671-1687

25. Ghazal, T., Hasan, M., Alshurideh M., Alzoubi, H., Ahmad, M., Akbar, S., Al Kurdi, B. \& Akour, I. (2021) IoT for Smart Cities: Machine Learning Approaches in Smart Healthcare-A Review, Future Internet, 13, 218. https://doi.org/10.3390/fi13080218

26. Ali, N., Ahmed, A., Anum, L., Ghazal, T., Abbas, S., Khan, M., Alzoubi, H. \& Ahmad, A. (2021) Modelling Supply Chain Information Collaboration Empowered with Machine Learning Technique. Intelligent Automation \& Soft Computing, 30(1): 243-257. DOI:10.32604/iasc.2021.018983

27. Analyzing the effect of knowledge management processes in the services' quality in Iraqi commercial banks. International Review of Management and Business Research, 5(1), 302-314. (2016)

28. Exploring the Impact of the use of Business Information systems BIS on the organizational performance effectiveness. International Journal of Business and Management Invention, 5(4), 48-55. (2016)

29. The Impact of Managers Efficiency on Quality of Strategic Decision-making under Crisis Management. European Journal of Business and Management, 7(26), 156-166. (2015)

30. Investigating the Relationship between Knowledge Management Processes and Organizational Performance: The Mediating Effect of Organizational Innovation. International Review of Management and Business Research, 4(4), 977-997 (2015).

31. The Impact of Business Process Management on Business Performance Superiority. International Journal of Business and Management Review, 3(2), 17-34 (2015)

32. Evaluating Strategic Quality Management Dimensions Using Analytic Hierarchy Process (AHP) and its Impact on Organizational Success. International Journal of Research in Management, 5(1), 137-150 (2015)

33. American Muslims' Perceptions Toward Transforming Islamic Banking System. International Journal of Economics, Commerce and Management, 5(1), 1-16 (2015)

34. Exploring the Relationship between Quality Orientation, New Services Development and Organizational Performance. American Academic \& Scholarly Research Journal, 5(3), 315-329 (2013)

35. Analyze the Impact of Managers Awareness of Environmental Uncertainty on Exploiting Strategic Competencies. Egyptian Journal for Commercial Studies, 34(2), 611-625 (2010)

36. Applying Electronic Supply Chain Management Using Multi-Agent System: A Managerial Perspective. International Arab Journal of e-Technology, 1(3), 106-113 (2010)

37. Propose a model for Performance Criteria and measuring its impact for Achieving Excellence, Association of Arab Universities Journal, 56 (4), 920-941. (2010)

38. S. Y. Siddiqui, A. Haider, T. M. Ghazal, M. A. Khan, I. Naseer, S. Abbas, M. Rahman, J. A. Khan, M. Ahmad, M. K. Hasan, A. M. A, and K. Ateeq, "IOMT cloud-based intelligent 
prediction of breast cancer stages empowered with Deep Learning," IEEE Access, vol. 9, pp. 146478-146491, Oct. 2021.

39. S. Abbas, Y. Alhwaiti, A. Fatima, M. A. Khan, M. Adnan Khan, T. M. Ghazal, A. Kanwal, M. Ahmad, and N. Sabri Elmitwally, "Convolutional neural network based intelligent handwritten document recognition," Computers, Materials \& Continua, vol. 70, no. 3, pp. 4563-4581, Oct. 2021.

40. T. M. Ghazal, S. Abbas, S. Munir, M. A. Khan, M. Ahmad, G. F. Issa, S. Binish Zahra, M. Adnan Khan, and M. Kamrul Hasan, "Alzheimer disease detection empowered with transfer learning," Computers, Materials \& Continua, vol. 70, no. 3, pp. 5005-5019, Oct. 2021.

41. N. Ali, T. M. Ghazal, A. Ahmed, S. Abbas, M. A. Khan, H. M. Alzoubi, U. Farooq, M. Ahmad, and M. Adnan Khan, "Fusion-based supply chain collaboration using Machine Learning Techniques," Intelligent Automation \& Soft Computing, vol. 31, no. 3, pp. 16711687, Oct. 2021.

42. M. K. Hasan, T. M. Ghazal, A. Alkhalifah, K. A. Abu Bakar, A. Omidvar, N. S. Nafi, and J. I. Agbinya, "Fischer linear discrimination and quadratic discrimination analysis-based data mining technique for internet of things framework for Healthcare," Frontiers in Public Health, vol. 9, Oct. 2021.

43. R. Bibi, Y. Saeed, A. Zeb, T. M. Ghazal, T. Rahman, R. A. Said, S. Abbas, M. Ahmad, and M. A. Khan, "Edge AI-based automated detection and classification of road anomalies in VANET using Deep Learning," Computational Intelligence and Neuroscience, vol. 2021, pp. 1-19, Sep. 2021.

44. M. Adnan Khan, T. M. Ghazal, S.-W. Lee, and A. Rehman, "Data Fusion-based machine learning architecture for intrusion detection," Computers, Materials \& Continua, vol. 70, no. 2, pp. 3399-3413, Sep. 2021. 